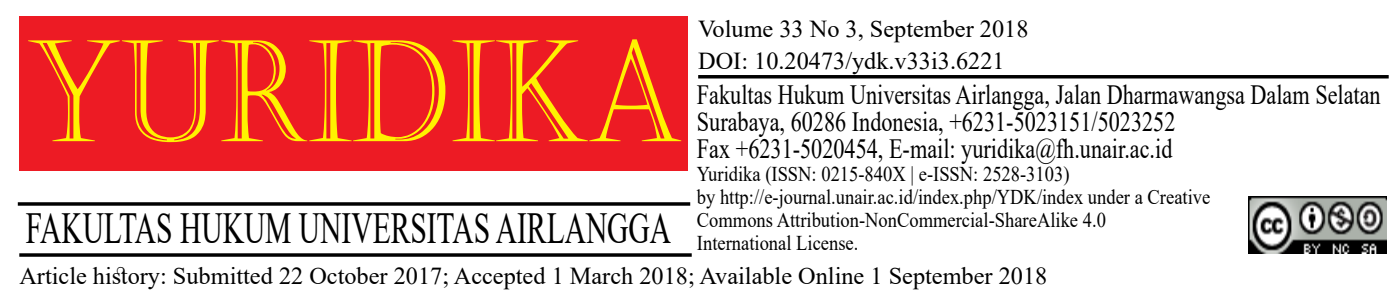

\title{
Parol Evidence Rule Doctrin as the Limitation for the Parties in Submitting Evidence Before the Court
}

\author{
Praditha Suraja Wahana \\ pradithasuraja@gmail.com \\ Paralegal
}

\begin{abstract}
Contracts that made by the parties as the basis of engagement are the perfect and strongest proof or facts when there is a contract dispute between the parties which made it. To be reliable then the contents of the contract must be guaranteed the truth. The doctrine parol evidence rule plays a big role to make that happen. This doctrine works primarily in the evidentiary stage of the trial by preventing the submission of evidences which is classified as an extrinsic evidence to be submitted to the courts, since such evidences is highly questionable and therefore potentially fraudulent. However, the application of a rigid and absolute parol evidence rule may also lead to unfavorable situations for contracting parties, so under certain conditions such doctrine by the judge may be overruled. The doctrine if implemented in Indonesia will be support in enforcement and application the articles in BW (Indonesian Civil Code), especially Articles 1342 and Article 1350 BW. Moreover, the application of this doctrine can also improve judicial efficiency in terms of time, cost and personnel. The parties will be benefited from the application of this doctrine, for instance it will protect the truth of the contents of the contract so as to prevent doubts about the contracts they have made and encourage the parties to promote the prudentially principle.
\end{abstract}

Keywords: Contract; Parol Evidence Rule; Extrinsic Evidence; The Evidentiary Stage. 


\section{Introduction}

In any business relationship an agreement is required. This Agreement will lead to an engagement for each party to implement what has been agreed by the parties beforehand. Engagement is a legal relationship between two persons or two parties, based on which one party has the right to demand something from the other, and the other party is obliged to fulfill the demand. ${ }^{1}$ In other words, the existence of the agreement will ensure that each party carries out its obligations and accepts what it deserves, because the agreement contains a binding engagement between the two parties. The agreement is generally by the parties written in writing so that what is the obligation of each party can be set clearly and clearly and ensure legal certainty. In order to guarantee promises in an agreement carried out by each party, then in addition to the agreement made in writing there must also be a rule of law governing it. In common law law is known the existence of doctrine parol evidence rule that seeks to protect a party in the agreement of statements and evidence both orally and in writing submitted by the opponent of his promise that tried to deny or refuse to fulfill his promise to the party.

In general, the parol evidence rule states that if an agreement has been signed by the parties, then the parties can not avoid or quit what has been stated in the agreement. The parol evidence rule has long been a controversial element of the commonlaw system. It has been frequently attacked for the funny results application and sometimes even for a lack of rationality in its justification. ${ }^{2}$ Application of the Parol Evidence Rule before signing a written statement, the parties negotiate orally. ${ }^{3}$ The doctrine makes many judges consider that what is written in the covenant is a truth and strong evidence that it has been the will of the parties to do, unless there is other evidence to the contrary. This view is known as the term rebuttable

${ }^{1}$ Subekti, Hukum Perjanjian (Intermasa 2005).[1].

2 Tony Cole, 'The Parol Evidence Rule: A Comparative Analysis And Proposal'(2003) 26 UNSW Law Journal <http://www.unswlawjournal.unsw.edu.au/wp-content/uploads/2017/09/26-3-14.pdf $>$.

${ }^{3}$ Liza Marina, 'Budaya Hukum Kontrak Bisnis Internasional (Studi Komparatif Aspek Budaya Hukum Pelaku Kotrak Bisnis Antara Masyarakat Penganut Sistem Hukum Civil Law Dan Common Law)' (2018) 1 Supremasi Hukum.[1]. 
presumption or praesumptio iuris tantum. As a result of the imposition of rigid doctrine, Richard Stone, gives attention to the preparation of contracts, where in making the contract is very important for the parties to use clear and explicit words. ${ }^{4}$ This is because judges in court will put forward the doctrine of the parol evidence rule and very seldom dig deeper to know the meaning of clauses in the contract unless it is necessary.

\section{Scope of Parol Evidence Rule Doctrine}

The doctrine parol evidence rule emerged under the enactment of the Statute of Frauds and Perjuries on 16 April 1677 in England. The enforcement of these rules is intended to avoid and reduce the occurrence of fraud, bribery and false witness in court. At that time the contract is commonly made only orally with the presence of witnesses from each party. As a result of the practice, the verification in court in the event of a contract dispute is largely based solely on oral evidence (parol evidence). The jurists and judges on their development many argue that the evidence in the Court that rely solely on the parol evidence has the potential to cause injustice. It is based on the notion that human memory is very limited in its capacity and it is not wise for the Court to issue a decision largely based on the parol evidence. ${ }^{5}$ Another consideration is that the parol evidence relies heavily on the witnesses who provide the information in the Court, and does not rule out the statements of the witness being subjective to the parties of powers, and prone to bribery and fraud directing witnesses to give false information.

Based on these circumstances, the statute of frauds and perjuries is enacted, with the rules requiring the contract to be made in writing and signed by both parties is expected to further ensure the legal certainty of a contract and provide justice for the parties to the contract. The enforcement of these rules at the same time limits the submission of parol evidence as the basis for proof in court, the restrictions on parol

\footnotetext{
${ }^{4}$ Richard Stone, Principles of Contract Law (4th ed, Cavendish, 2000).[140].

5 Richard Wilmot dan Smith QC, Construction Contracts: Law and Practice (Oxford University Press 2010).[26].
} 
evidence are then set in its own doctrine known as the doctrine parol evidence rule. Clark and Kinder argue that the parol evidence rule is: "the rule that excludes extrinsic evidence from the prior or contemporaneous agreement that alter or contradict a written contract intended to be the final and complete expression of the parties". ${ }^{6}$

Then Ronald Anderson, explains two basic principles of the doctrine parol evidence rule. The first principle is that the doctrine parol evidence rule assumes that there has never been an oral agreement, and the second principle states that although there is agreement, the agreement is deliberately ignored by the parties by excluding it into a written contract to be signed the parties. ${ }^{7}$ Oral agreements referred to by this principle are oral agreements made or spoken before or at the time the contract is made. Furthermore, Ronald Anderson states that these two basic principles are intended to ensure that the doctrine of the parol evidence rule provides stability to the contract and prevents claims based on oral evidence that actually never existed. ${ }^{8}$ Another legal expert, Richard Stone, states that the doctrine of the parol evidence rule is a doctrine which, when applied, would rule out the possibility for either party to insist that some part of the written contract be ignored or interpreted contrary to what is written in the contract, with the words and notes the meaning of the contract is clear. ${ }^{9}$ Based on the opinion of these experts, in general parol evidence rule is a doctrine that limits the parties to propose parol evidence (which in its development is not limited to oral evidence only, but includes also writings and agreements made before or at the time the contract is signed) with a view to altering or adding meaning or provisions contrary to what has been contained in the contract. ${ }^{10}$

The idea behind the emergence of the doctrine parol evidence rule is to ensure the legal certainty of a contract and the application of prudential principles.

${ }^{6}$ Lawrence S. Clark dan Peter D. Kinder, Law and Bussiness (2rd edn, McGraw - Hill Inc 1988).[175].

7 Ronald A Anderson,[et.,al.], Business Law (12th edn, Western Publishing Co 1984).[189].

8 ibid.

9 Richard Stone (n 4).Loc. Cit.

${ }^{10}$ Lawrence S. Clark dan Peter D. Kinder (n 6).Op.Cit.[76]. 
Through the doctrine it is expected that the contract made by the parties is a clear or complete statement or final agreement between the two parties, so that it becomes the best evidence of the willingness of the parties. ${ }^{11}$ The law with no certainty value will lose its identity and meaning, because it can no longer be used as a guideline of everyone's behavior as adagium "Ubi Juice Incertum Ibi Jus Nullum”. The same is true of contracts made by the parties where without any certainty as to the truth of the contents of the contract, the contract will be doubtful and unreliable as a means of proof. The existence of the Parol evidence rule doctrine is expected to ensure the certainty of the truth of the contents of the contract, so that the parties can rely on the contract they have made as the basis of the bond between them and as a means of verification in case of a contract dispute in the future. However, it does not rule out the doctrine of parol evidence rule can be detrimental to the parties, if in making the contract the parties are not careful and careful. Based on this, in addition to protecting the interests of the parties in the contract, the doctrine parol evidence rule can also be detrimental to the interests of the parties if not careful. According to Lawrence S. Clark, it is important to read and understand the contents of the contract before the parties sign it as "read before you sign, study the document to make sure it represents your agreement. If it does not or if you do not understand a clause, the burden is on you to have the contract altered in writing before you sign". ${ }^{12}$ This is where the doctrine parol evidence rule requires that the parties prioritize the principle of prudence in making and signing contracts, so that doctrine does not turn out to harm the parties.

\section{The Application of Parol Evidence Rule}

In general, the doctrine of parol evidence rule can apply to almost all commercial contracts made by interested parties. One basis for the validity of the parol evidence rule doctrine is that the contracts made by the parties are written contracts, although in countries of common law law and other countries which

\footnotetext{
11 John D. Donnell,[et.,al.], Law For Business (Richard D Irwin Inc 1983).[155].

${ }^{12}$ Lawrence S. Clark dan Peter D. Kinder (n 6).Op.Cit.[174].
} 
impose similar doctrines the provisions on such matters are not regulated firm and clear, so that in some cases parol evidence rule may also apply to oral contracts, especially in the field of trade. This refers to the opinion of Richard Mann and Barry Robert who declared "the law of sales also involves a number of written and oral contracts to which the parol- lid rule may be applied". ${ }^{13}$ It is generally known that written contracts are the strongest and undisputed evidence of contracts made by the parties, especially if they are used as evidence in the Court. This is in line with John Donnell's stated opinion: ${ }^{14}$

"This is generally true since the terms of the writing are known and irrefutable, whereas oral statements by the parties after a dispute has arisen may be affected by faulty memory, wishful thinking, or outright bad intent. Even prior writings made by the parties may only represent preliminary sbjects of negotiation by the parties which were never agreed to".

Written statements are higher in rank as evidences than statements made only orally. This is because if the evidence is made, then the oral statements are very vulnerable influenced by the mistake of remembering, personal opinion, or bad faith from giving a statement. A similar opinion is also expressed by Yahya Harahap who expressed that the evidence that is considered dominant and determinant is the evidence of the letter, whereas the witness basically does not play a role, especially in the business transaction case. ${ }^{15}$ Taking into account the opinions of these experts, it is true that in most cases where contract clauses are clearly stated and the meaning is straightforward, the court judge will impose a parol evidence rule if there are parties who submit parol evidence as a basis for altering or declaring matters as opposed to the closed contract clauses. It was recently held in the Supreme Court of Appeal (SCA) that "a court may not admit evidence as to what the parties intended it to mean if that has the effect of changing the terms of which they clearly agreed (in writing)". ${ }^{16}$ For example, the case of Continental Life against Nyonya Songer,

\footnotetext{
${ }^{13}$ Richard A. Mann dan Barry S. Roberts, 'Essentials of Business Law and The Legal Environment' (Legal Dictionary Thefreedictionary, 2008).

${ }^{14}$ John D. Donnell (n 9),[et.,al.].Loc.Cit.

${ }^{15}$ M. Yahya Harahap, Hukum Acara Perdata (9th edn, Sinar Grafika 2009).[557].

${ }^{16}$ Kirith P.Haria, 'Contract Law : Parol Evidence Rule' (Polity, 2013) < http://www.polity. org.za/article/contract-law-parol-evidence-rule-2013-04-19> accessed 21 May 2017.
} 
where there has been an insurance agreement between Continental Life and Mrs. Songer. ${ }^{17}$ The insurance agreement states that the implementation of the protection against injury suffered from an accident can only be made after the application form is approved by the head office. Before the insurance agreement is signed, the insurance agent promises Mrs. Songer that in case of an accident he promises to submit the application form to the head office immediately. Sometime later Mrs. Songer had an accident and Continental Life refused to make any payment on the grounds that she had not received Mrs. Songer's application form. The Arizona State Court in its verdict stated that in the insurance agreement it was clear that the protection against accidents could only be made after the application form was approved by the head office, the judge considered that the clause was clear and unambiguous, thus based on the doctrine parol evidence rule the judge rejected the submission of parol evidence (the insurance agent's pledge against Mrs. Songer) as evidence in the hearing. If the parol evidence is allowed by the judge to be brought before the court, then it should further strengthen the validity of the doctrine parol evidence rule because the proposed parol evidence is contrary to what has been stated in the insurance agreement.

One of the basic ideas of the doctrine parol evidence rule is based on the idea or principle in society which states that "today may control the effect of what happens today". ${ }^{18}$ The thought has an effect on the principle of the validity of the doctrine parol evidence rule as Lawrence S. Clark and Peter Kindler argue that "it is important to note that parol evidence rule applies to evidence relating only to events or writing which took place before or at the same time as the agreement was executed". ${ }^{19}$ This means that the validity of the doctrine parol evidence rule is only on the parol evidence or extrinsic evidence made or occurs before or at the time of contract closure, so that a contrario parol evidence rule does not apply to evidence

\footnotetext{
${ }^{17}$ Continental Life \& Accident Co. v Songer (124 Ariz 294, 603 P2d 921 (1979)) in Ronald A Anderson (n 5),[et.,al.],Op.Cit.[190].

18 Arthur Corbin, 'The Parol Evidence Rule' (1944) 53 The Yale Law Journal < http://digitalcommons.law.yale.edu/cgi/viewcontent.cgi?article=3900\&context=fss_papers $>$.

${ }^{19}$ Lawrence S. Clark dan Peter D. Kinder (n 6).Loc.Cit.
} 
that occurs after the contract is closed or if there is a modification or addendum to the contract. To clarify the validity of the doctrine parol evidence rule against parol evidence or extrinsic evidence that occurred before the closure of the contract or contract was signed as follows: ${ }^{20}$

1. Pre Contractual, Parol evidence rule prohibits Contradiction of final agreement by understanding, negotiations, pre eliminary and contemporaneous agreements;

2. Closing Contract, Parol evidence rule does not prohibit evidence of subsequent modification of the contract.

It is clear that the doctrine of the parol evidence rule can not be applied to evidence or agreements that occur after the contract is signed or closed. This is because the evidence and the agreements are considered not part of a fully written contract or complete (complete written agreement or integrated agreement) which has been signed by the parties, and usually has consideration ${ }^{21}$ which is different from the closed contract, so that both the evidence and the treaties are regarded as the second agreement related to the first, the original, the agreement made by parties or the subsequent agreement. ${ }^{22}$ In this case McCarthy against Harrington ${ }^{23}$ can be used as an example, where in the sitting case there has been a construction contract between McCarthy as the owner and Harrington to build a house. The construction contract states that there will be no payment of additional work unless otherwise stated in writing and accompanied by a price breakdown of the added employment. After the construction went on, McCarthy verbally asked Harrington to do some added

${ }^{20}$ Mark E. Rozkowski, Business Law: Principles, Cases and Policy (3rd edn, HarperCollins Publishers Inc 1992).[272].

${ }^{21}$ Consideration in the Common Law legal system is something that has value obtained because it has carried out achievements in a contract. In the business consideration is usually in the form of money or objects of value and can be exchanged. Nancy K. Kubasek, Dynamic Business Law (McGraw - Hill Irwin 2009).[384]. In other words consideration is something that is given, promised, or done reciprocally. Its nature can be either "will be implemented" or "already implemented". Abdul Kadir Muhammad in Salim HS, Perancangan Kontrak \& Memorandum of Understanding (MoU) (4th edn, Sinar Grafika 2008).[15].

${ }_{22}$ Law Teacher Essay, 'Exceptions To The Parol Evidence Rule Contract Law' (Lawteacher, 2014) <https://www.lawteacher.net/free-law-essays/contract-law/exceptions-to-the-parol-evidencerule-contract-law-essay.php?cref=1> accessed 23 May 2017.

23 Harrington v McCarthy (91 Idaho 307, 420 P2d 790 (1966)). In Ronald A Anderson (n5),[et.,al.].Op.Cit.[193]. 
work without written orders. After the construction work and added work done by Harrington McCarthy refused to make payments to the added work that Harrington did on the grounds there was never a written order to do the added work so that the doctrine of parol evidence rule applies. In the trial the Judge allowed the parol evidence of an oral agreement between McCarthy and Harrington to do the added work presented as evidence in the Court, through the evidence that the Judge ruled that McCarthy had to pay for the added work Harrington had done. On the verdict, the Judge is of the opinion that "The fact that the original contract contained a requirement of written work modifications did not prevent the proof that the parties had proceeded in disregard of such requirement and thereby modified the original contract with respect to the work done". ${ }^{24}$ Through such court decisions it can be seen that the doctrine of the parol evidence rule can not be enforced to obstruct existing evidence after the contract is closed for submission in the Court. In other words, the parties within the contract can not take refuge behind the doctrine of the parol evidence rule if the opposing party submits the parol evidence that exists after the contract is closed as evidence in the Court.

The validity of the parol evidence rule doctrine in addition to the written contract and to the parol evidence before the contract is closed, it must also consider whether the contract is included in the integrated contract group or not. This is important, since the doctrine parol evidence rule can only apply to the integrated contract or contract with clauses of a final agreement between the parties. This can be seen from Donnell and Barnes: ${ }^{25}$

"When the parties to a writing intend it as an integration, a complete and final embodiment of the terms of the agreement, parol evidence can not be used to add to or vary its terms. However, when the agreement was not an integration, parol evidence can be used to prove elements of the agreement that were not reduced to writing".

If the contract is not a complete unity, for example there are written clauses and some other clauses in oral form, then the parol evidence rule can not be applied, this

\footnotetext{
24 ibid.

25 John D. Donnell (n 9),[et.,al.].Op.Cit.[157].
} 
is because in such a contract, generally the judge will allow parol evidence shall be submitted as evidence as long as it does not contradict the contents of the contract, in order to delve deeper into the intent and will of the parties.

The distinctive feature of integrated contract is merger clause, ${ }^{26}$ namely the clause in the contract stating that the contract is a final agreement between the two parties, so that it can not be interpreted or interpreted other than what has been agreed upon, unless there is a written agreement from both parties. To clarify, here is an example of a merger clause: "except as is otherwise provided herein, this (Lease or Agreement) constitutes the entire agreement among the parties with respect to the subject matter contained herein and supersedes all other agreements, letters, memoranda, or any other prior understanding of any type whatsoever, whether written or oral". ${ }^{27}$

However, the parties should set up an integrated contract not merely to rely on merger clause, but also to carefully arrange clauses within the contract to reflect that the contract is final and clear. In this regard, the judge's opinion in Addy's case against Piedmonte is as follows: “...determining whether a contract is fully integrated, the court focuses on whether it is appropriate and formally drafted. the subject matter, and whether it expresses the final intentions of the parties". ${ }^{28}$ Taking note of this, it is possible to judge another opinion on the "integrated" nature of the contract proposed by the parties as evidence in the hearing. In addition to factors as discussed earlier, according to Richard Stone the enactment of the parol evidence

\footnotetext{
${ }^{26}$ Merger Clause is a clause in the contract which states that the contract is a final agreement between the two parties both in terms of understanding and meaning of the contract clauses. Vinay Jain, 'The Merger Clause of A Contract' (Shake Law, 2014) <http://www.shakelaw.com/blog/ the-merger-clause-of-a-contract/> accessed 26 May 2017. In general, the merger clause is used so that the parties do not deny the clause in the contract by denying it or interpreting it other than the one stated in the contract.; Charles T. Williams dan Wilmington, 'Avoiding and Resolving Contract Conflicts Integration Clauses' (ACC America, 2013).

${ }^{27}$ Trainor Fair Brook, 'Integration Clause and The Parol Evidence Rule' (Trainor Fair Brook, $2017)<$ https://trainorfairbrook.com/attachments/0006/4568/IntegrationClauses.pdf \%3E $>$ accessed 26 May 2017.

${ }_{28}$ Addy v. Piedmonte, 2009 WL 707641 (Del. Ch. 2009), Charles T. Williams dan Wilmington (n 26).Loc Cit.
} 
rule doctrine is also influenced by the following matters: ${ }^{29}$

1. Skill and Knowledge of the Parties

The skills and knowledge of the parties on the object of the contract they agree on can determine whether the doctrine parol evidence rule can be applied or not, especially if there is a difference in skill level and knowledge between one party to another. This is because the skill level and knowledge are often used by judges in the Court to determine whether the preliminary agreement or parol evidence may be considered part of the contract or not. If one party has more skills and knowledge about the object of the contract than the other, then the party has a superior position, because he is considered able to guarantee the truth of what it states. This is of course a surplus value because judges have great potential to consider what it claims to be part of the contract. Such circumstances certainly make the doctrine parol evidence rule can not be applied. However, it is also possible that the skill and knowledge level makes what it claims to be not considered part of the contract.

In such circumstances the doctrine parol evidence rule becomes applicable. An example is the case of Oscar Chess Ltd against Williams (1957),${ }^{30}$ where in this case there has been a sale and purchase of cars between Williams as an individual with Oscar Chess Ltd. as a car dealer. Prior to the sale and purchase contract, Williams declared that the car he was selling was in production in 1948, but after the sale and purchase it was found that the car was in production in 1939. In the trial the judge won Williams and stated that the parol evidence of Williams's statement about the year of production of the car is not part of the contract, so as to apply the doctrine parol evidence rule. The judge's opinion in his verdict states that as a car dealer Oscar Chess Ltd should have better skill and knowledge about the car's condition than Williams, for example by checking the engine number and frame of the car, but it is not done.

2. Lapse of Time between the Statement and the Contract

In the event of a dispute between the parties concerning the contract, the

\footnotetext{
${ }^{29}$ Richard Stone (n 4).Op.Cit.[133].

${ }^{30}$ Oscar Chess Ltd v Williams ( (1957) 1 All ER 325; (1957) 1 WLR 370),ibid.[134].
} 
time difference between what the parties declare (in this case parol evidence) with the time when the contract is signed or closed becomes an important element to be noticed by the judge in the hearing. This is because the closer the time is the greater that what is stated can be considered a judge as part of the contract and vice versa the longer the time the greater the potential of the judge to refuse the parol evidence submitted to the hearing. Seeing this, the further distance between the parol evidence and contract, the strength of proofing the parol evidence is getting weaker. As the strength of proof of parol evidence weakens then this is where the doctrine parol evidence rule has a great possibility to apply. This means that the time span between the parol evidence and the time at which the contract is signed has an effect on whether or not the doctrine of parol evidence rule is enforced. An example is the case of Routledge against McKay, (1954) ${ }^{31}$ where the case regarding the contract of sale and purchase of a motorcycle that sat his case was Routledge as the seller was sued by Mckay as the buyer. Before the sale and purchase agreement was signed a preliminary agreement had occurred, in which Routledge declared that the motorcycle it was selling was in production in 1942, for which Mckay stated his willingness to buy the motorcycle. The contract of sale and purchase of motorcycles was signed by both parties months later after the preliminary agreement. After some time it turns out that the motorcycle production in 1939, on this fact Mckay filed a lawsuit on Routledge. In the trial the Judge won the Routledge and stated that the information provided by Routledge at the time of the preliminary agreement was not part of the contract, so that it was only considered parol evidence, hence enacted the doctrine parol evidence rule. This is also based on several facts, such as the absence of clauses on motorcycle specifications and the year of production in the contract, the positions of both parties who have the same level of skills and knowledge of the contract object as well as the time interval between the parol evidence and the contract considered too far. In the latter fact

${ }^{31}$ Routledge v McKay ( (1954) 1 All ER 855; (1954) 1 WLR 615).ibid.[135]. 
the judge is of the opinion that too much distance between the parol evidence and the contract makes the parol evidence doubtful and weakens the strength of the proof, so that the burden of risk is on the Pengugat. Through this fact the judge imposed the doctrine parol evidence rule, thus rejecting the Param evidences submitted by the Plaintiff.

\section{Waiver of the Parol Evidence Rule}

A rule of law should provide benefits and convenience to its users, rather than providing a burden that complicates and potentially leads to injustice, so in its application a rule of law must have a flexible nature. Aristotle in his book Rhetorica argues that justice is if everyone gets his share (ius suum cuique tribuere). ${ }^{32}$ The opinion is also in line with what Ulpianus states is "Iustitia est perpetua et constans voluntas ius suum cuique tribuendi" which when translated is justice is a constant and constant desire to give to people what is its part. ${ }^{33}$ Seeing the opinions of these philosophers then justice does not always connotes with equality, in other words justice does not mean giving everyone the same part. If the thinking of such experts is applied in the implementation of the rule of law or the doctrine of the law, it is unfair that a rule of law or legal doctrine applies in absolute terms. There are certain circumstances in which if the rule or doctrine of law is applied it will lead to injustice. The same is true of the doctrine parol evidence rule, in which there are certain circumstances within the contract that result in the doctrine parol evidence rule being overruled.

The waiver of the parol evidence rule doctrine within a commercial contract is solely intended to ensure that the business activities that have been framed by the parties in the contract can proceed smoothly and to uphold the principle of fairness in contracting. A waiver of the parol evidence rule doctrine may occur if there are circumstances as will be explained as follows:

1. An Ambiguous Clause in the Contract

\footnotetext{
${ }^{32}$ Peter Mahmud Marzuki, Pengantar Ilmu Hukum (Prenadamedia Group 2015).[131].

33 ibid.[133].
} 
An ambiguous contractual clause may rule out the enactment of the parol evidence rule doctrine. This is because if in a contract encountered ambiguous clauses, then other evidence including parol evidence may be submitted to delve deeper into the actual intent of both parties. Ambiguity often occurs because of the language factor used in the contract or the facts that occur in the field. Nancy Kubasek argues that: ${ }^{34}$

"To attempt to reach the most accurate interpretation of the original document, the court allows evidence, even if it is oral. As with the evidence regarding orally agreed-on condition precedents, evidence used to clarify ambiguity is believed not to modify the contract but, rather to clarify. Accordingly, oral evidence related to ambiguity is admissible only to clarify, and not to change any contractual terms".

It should be noted that in this case the parol evidence rule is ruled out against the parol evidence submitted solely to clarify or clarify the ambiguous clause, not the parol evidence that seeks to change or add to the meaning of the contract clause that has been closed by the parties. The exclusion of the doctrine parol evidence rule due to this ambiguity in the United States is governed by the Uniform Commercial Code (hereinafter referred to as UCC) in Part 2 Article 202:

"Terms with respect to which the confirmatory memoranda of the parties agree ... may not be contradicted by evidence of any prior agreement or of a contemporaneous oral agreement but may explained or supplemented a). by course of dealing or usage trade or by course of performance; and b). by evidence of consistent additional terms ...".

This means that the parol evidence in this case is a course of dealing, a usage trade, a course of performence and other proofing evidence allowed to be submitted as long as the purpose of explaining is not to change and remove the existing meaning. Similar arrangements are also found in Indonesian civil law, namely in Article 1343 BW which reads "If the words of a covenant can be given various interpretations, it should be chosen to investigate the intentions of both parties that make the covenant, words by letter ". However, in the BW is not more clearly defined whether in order to investigate the intentions of both parties

${ }^{34}$ Nancy K. Kubasek (n 21).[et.,al.].Op.Cit.[473]. 
may be submitted also parol evidence which is to change or add meaning to the contract that has been closed by the parties.

Examples of cases of exclusion of the parol evidence rule doctrine due to ambiguity in the contract clause can be seen in the Olsen Media case against Energy Sciences where the sitter Energy Sciences holds a contract to advertise with Olsen Media as an advertising services agency. ${ }^{35}$ The contract states that every month Olsen Media will get paid and the amount of the "negotiable" payment after the contract runs for six months. The contract also includes a merger clause stating that the clauses in the contract are the final agreement of both parties. After six months there was a difference of opinion about the meaning of "negotiable" by both parties, so the case was brought to court. In the trial Olsen Media submitted a parol evidence which indicated that the "negotiable" meaning was a negotiated payment with a higher bid than the payment for the first six months of the contract, not the other way around. The evidence is denied by Energy Sciences which states that the contract includes a merger clause so it should apply the doctrine parol evidence rule which prohibits parol evidence being filed. In its verdict the judge stated that the merger clause does not prevent the allowance of parol evidence to be submitted to the court, this is because parol evidence is used to explain "negotiable" clauses containing ambiguity.

2. Contracts are modified after being concluded by the parties

The contracts which are changed or modified by the parties, can not be applied to the doctrine parol evidence rule against it. Especially concerning the evidence that occurred due to the modification. However, what needs to be noted is that the modification must be done after the contract is closed by the parties, because otherwise the doctrine parol evidence rule can still be applied. In this statement "to be admissible, the modification must have been made after the writing, and the evidence must clearly indicate this later modification". ${ }^{36}$ The statement is in

35 Olsen Media v Energy Sciences (32 Wash App2d 579, 648 P2d 493 (1982)).Ronald A Anderson,[et.,al.].[191].

${ }^{36}$ Nancy K. Kubasek (n 20).[et.,al.].Op.Cit.[472]. 
conformity with the basic principle for the validity of the parol evidence rule doctrine as described previously only to limit the evidence existing or to occur before or when the contract is closed by the parties."'The parol evidence rule prohibits only the contradiction of a complete written contract, it does not prohibits proof that the contract was thereafter modified or terminated". ${ }^{37}$ This means that the waiver of the doctrine parol evidence rule in these circumstances should also take into account how the contractual modification occurs. In some cases it should be noted whether the statute of frauds doctrine applies to the contract, if applicable, the modification of the contract must be made in writing. In the event of such a condition, the verbally modified contract will result to an "unenforceable" circumstances. ${ }^{38}$ Modification of contracts declared "unenforceable", then the evidence derived from such modifications can not be brought to the hearing so that the doctrine parol evidence rule may apply to it.

3. Written contracts whose implementation is based on oral conditions

The parol evidence rule doctrine is ruled out against parol evidence which is a requirement that must be fulfilled as a basis for the execution of the contract. The reason for the parol evidence rule is ruled out when Nancy Kubasek finds such a situation "the evidence being elicited does not substantially modify the written agreement. No terms are altered, so the parol evidence rule does not apply". ${ }^{39}$

Agreeing with the statement, Mark Roszkowski in his book Business Law said that "evidence of the existence of the condition is not subject to the parol evidence rule". ${ }^{40}$ As an illustration of the case, exemplified as follows $\mathrm{A}$ is a homeowner and $\mathrm{B}$ is a potential buyer. Before the sale and purchase of the house is closed, A and B agree verbally that the payment of the house price will be made if $\mathrm{B}$ gets a home loan or loan from third parties. In case of a contract dispute and A then demands

\footnotetext{
${ }^{37}$ Ronald A. Anderson (n 5).[et.,al.].Loc.Cit.

38 If it is translated freely, it cannot be demanded in court. The Black's Law Dictionary defines it "defective but valid contract unable to be enforced by court", Briyan A. Graner, "Unenforceable', Black's Law Dictionary (10th edn, Thomson Reuters 2009) < http://thelawdictionary.org/ unenforceable-contract/>.

${ }^{39}$ Nancy K. Kubasek (n 21).[et., al.].Loc.Cit.

${ }^{40}$ Mark E. Rozkowski (n 20).Op.Cit.[276].
} 
payment, then B may submit a parol evidence explaining that the implementation of obligation B depends on its ability to obtain a loan of funds. Parol evidence which is a prerequisite for the implementation of the contract in the common law law system is known as condition precedent. ${ }^{41}$ Condition precedent this is separate from the contracts that have been closed by the parties, so it can not be used to change the contents of the contract. Contracts with such prerequisites are categorized as non integrated contracts and as explained earlier that the parol evidence rule can only be applied to the integrated contract.

4. Contracts with partially written forms and some others oral (Incomplete/Non Finalized Written Contract)

If parties can demonstrate that the written contract they have closed does not contain all of the clauses they agreed on, then parol evidence or extrinsic evidence may be submitted to supplement the deficit. The reason for disregarding the parol evidence rule in such circumstances is that in such a contract it does not reflect the final and complete agreement of both parties, so further evidence is required including parol evidence if any, to supplement the lack of such contract. Ronald A. Anderson argues "if the written contract is on its face, or is admittedly, not a complete summation, the parties naturally did not intend to abandon the points upon which they agreed but which were not noted in the contract; and parol evidence is admissible to show the actual agreement of the parties". ${ }^{42}$

As an example is a well-known case that records in the application of the doctrine parol evidence rule that is the case of Allen against Pink, ${ }^{43}$ where in this case there has been a horse sale agreement between Allen and Pink. The contract contains only the names of the parties and the price of the horse being sold and does not contain other clauses of explanation, in the trial the judge considers the

\footnotetext{
${ }^{41}$ In the Black's Law Dictionary interpreted a rule in a contract that parties must do what they agree to or a demand can be placed to perform the action required. "When an entire contract conditioned on something occuring first, the first thing is known as a condition precedent.".see: Nancy K. Kubasek (n 21).[et.,al.].Loc.Cit.

42 Ronald A Anderson (n 5),[et.,al.].Loc.Cit.

${ }^{43}$ Allen v Pink (4 M \& W 140 (1838)), Richard Stone (n 4).Op.Cit.[140].
} 
contract incomplete and permits the submission of parol evidence in the form of a verbal explanation of the seller to the buyer concerning the name of the horse, its characteristic and character when in the cage. Parol evidences are permitted to be submitted because of the "incomplete" contract with no mention of horse details as the object of sale and purchase. Determining whether a contract is complete or incomplete is not an easy matter, since there is no official rule governing how the form of the contract should be complete, which the judge can do in court is to assess whether substantial matters for the contract and the things in general there is a contract has been entered into the contract or not.

5. A contract that clearly had a writing error (Typographical Errors)

If in a written contract it is obvious that there have been typo errors concerning the important parts of the contract, then the parol evidence is permitted to be filed in order to show or prove that the error occurred solely because of typo errors intends to amend or supplement the contents of such contract and to return the contract to fit as agreed by the parties. The permission of the parol evidence rule submitted to correct misstatement can not be interpreted as a change to a written contract, since the true words that have miscalculated are not a reflection of the will of the parties as stated by Nancy Kubasek: ${ }^{44}$ "Allowing parol evidence to correct typos does not fundamentally alter the written agreement because the typo is not accurate reflection of the parties' agreement. The agreement is not altered by correcting a typo; rather the agreement is granted better clarity".

6. Canceled or revocable agreement (void or voidable contracts)

Parol evidence rule does not apply to a canceled or canceled agreement. If necessary, the Court allows the agreement to be void or voidable to be proven by the parol evidence. Basically in the event of such conditions, then also apply the principles as applicable to the things that cause pengampampin parol evidence rule. "Allowing evidence proving a contract is void or voidable does not fundamentally alter the terms of the contract. Rather, the parol evidence would

${ }^{44}$ Nancy K. Kubasek (n 21).[et.,al.].Op.Cit. [474]. 
address the enforce ability of the agreement, which is not the same as changing the terms of the agreement". ${ }^{45}$

7. The existence of the provisions regarding the start date or expiry date of the contract (starting or finishing date)

If a contract is determined on the date of its effective entry or expiration, then such a contract of such extrinsic evidence, including a parol evidence may be filed to indicate and prove that the contract can not be commenced or terminated prior to the date on which the parties have agreed. With regard to the terms of the effective contract to begin and end in this contract, Richard Stone argues: "extrinsic evidence may be used to establish the date on which a contractis intended to start to operate. In Pym v Campbell (1856), evidence was allowed as to an oral provision that the contract should not start to operate prior to the approval of a third party". ${ }^{46}$

8. The existence of customs in a commercial transaction or business transaction (evidence of course of dealing or usage trade or course of performance)

Often the habit of trading in a business activity has some constraints when framed into a contract. One of them is about the shift of meaning. Often the obvious words in a contract turn out to have a different meaning when translated with the prevailing trade habits. For example in the case of Smith against Wilson the words in the contract have clearly mentioned "1000 rabbits", but in trade habits this is interpreted as " 1200 rabbits" and the judges accepted the trademark as the true meaning of the contract ${ }^{47}$ Therefore, in a business contract that trade customs can apply to it, the court overrides the application of the parol evidence rule, this is because often the differences in the meanings of words between those listed are contracted and in trade habits can be explained and proven by extrinsic evidence including parol evidence. In this regard Parke B argues:"it has long been settled that, in commercial transactions, extrinsic evidence of custom and usage

\footnotetext{
45 ibid.

${ }^{46}$ Richard Stone (n 4).Op.Cit.[141].

47 Smith melawan Wilson (3B \& Ad 728 (1832)) in ibid.
} 
is admissible to annex incidents to written contracts in matters with respect to which they are silent". ${ }^{48}$ The waiver of the parol evidence rule due to trade habits in the United States is regulated in the Uniform Commercial Code, ie in Part 2 Article 202:" Terms with respect to which the confirmatory memoranda of the parties agree ... may not be contradicted by evidence of any prior agreement or of a contemporaneous oral agreement but may explained or supplemented: a) by course of dealing or usage trade or by course of performance; and b) by evidence of consistent additional terms ...".

\section{Conclusion}

Since the introduction of the Statute of Frauds and Perjuries in England, the doctrine of the parol evidence rule has received great attention and is undergoing rapid development. The common law law system even applies the doctrine as one of the substantive laws. Basically the doctrine parol evidence rule is a protection for the parties to the contract they have closed and agreed. Parol evidence rule seeks to prevent possible lies by the parties on the basis of actual evidence never existed, so the truth of the contents of the contract is unquestionable and the contract is truly reliable by the parties as the basis of the engagement, the basic rights and the basis of the obligation for the parties that make it. The doctrine also provides efficiency within the judicial system, especially in this case the judge may override or deny the evidence of the parties contrary to the contents of the contract made by the parties.

This is a very good breakthrough because judges do not need to spend energy, cost and time to prove the arguments of the parties that have not been clear. In addition, the parol evidence rule doctrine also encourages parties to contract to uphold the principle of prudence in contracting. The existence of such doctrines should encourage the parties to be more cautious, that is, to fully understand and understand all the clauses contained in the contracts they will sign. However, as is

48 ibid. 
usually the case with a legal doctrine, the parol evidence rule also has the potential to be ruled out in the trial. There are certain conditions, where if such doctrine is imposed, it would result in injustice to the parties in a contract.

\section{Bibliography}

Arthur Corbin, 'The Parol Evidence Rule' (1944) 53 The Yale Law Journal <http:// digitalcommons.law.yale.edu/cgi/viewcontent.cgi?article $=3900 \&$ context $=$ fss papers>.

Briyan A. Graner, 'Unenforceable', Black's Law Dictionary (10th edn, Thomson Reuters 2009) <http://thelawdictionary.org/unenforceable-contract/>.

Charles T. Williams dan Wilmington, 'Avoiding and Resolving Contract Conflicts Integration Clauses' (ACC America, 2013).

John D. Donnell, Law For Business (Richard D Irwin Inc 1983).

Kirith P.Haria, 'Contract Law : Parol Evidence Rule' (Polity, 2013) <http://www. polity.org.za/article/contract-law-parol-evidence-rule-2013-04-19> accessed 21 May 2017.

Law Teacher Essay, 'Exceptions To The Parol Evidence Rule Contract Law' (Lawteacher, 2014) <https://www.lawteacher.net/free-law-essays/contractlaw/exceptions-to-the-parol-evidence-rule-contract-law-essay.php?cref $=1>$ accessed 23 May 2017.

Lawrence S. Clark dan Peter D. Kinder, Law and Bussiness (2rd edn, McGraw Hill Inc 1988).

Liza Marina, 'Budaya Hukum Kontrak Bisnis Internasional (Studi Komparatif Aspek Budaya Hukum Pelaku Kotrak Bisnis Antara Masyarakat Penganut Sistem Hukum Civil Law Dan Common Law)' (2018) 1 Supremasi Hukum.

M. Yahya Harahap, Hukum Acara Perdata (9th edn, Sinar Grafika 2009).

Mark E. Rozkowski, Business Law: Principles, Cases and Policy (3rd edn, HarperCollins Publishers Inc 1992).

Nancy K. Kubasek, Dynamic Business Law (McGraw - Hill Irwin 2009).

Peter Mahmud Marzuki, Pengantar Ilmu Hukum (Prenadamedia Group 2015). 
Richard A. Mann dan Barry S. Roberts, 'Essentials of Business Law and The Legal Environment' (Legal Dictionary Thefreedictionary, 2008).

Richard Stone, Principles of Contract Law (4th ed, Cavendish, 2000).

Richard Wilmot dan Smith QC, Construction Contracts: Law and Practice (Oxford University Press 2010).

Ronald A Anderson, Business Law (12th edn, Western Publishing Co 1984).

Salim HS, Perancangan Kontrak \& Memorandum of Understanding (MoU) (4th edn, Sinar Grafika 2008).

Subekti, Hukum Perjanjian (Intermasa 2005).

Trainor Fair Brook, 'Integration Clause and The Parol Evidence Rule' (Trainor Fair Brook, 2017) <https://trainorfairbrook.com/attachments/0006/4568/ IntegrationClauses.pdf \%3E $>$ accessed 26 May 2017.

Tony Cole, 'The Parol Evidence Rule: A Comparative Analysis And Proposal' (2003) 26 UNSW Law Journal <http://www.unswlawjournal.unsw.edu.au/ wp-content/uploads/2017/09/26-3-14.pdf $>$.

Vinay Jain, 'The Merger Clause of A Contract' (Shake Law, 2014) <http://www. shakelaw.com/blog/the-merger-clause-of-a-contract/> accessed 26 May 2017.

HOW TO CITE: Praditha Suraja Wahana, 'Parol Evidence Rule Doctrin As The Limitation For The Parties In Submitting Evidence Before The Court' (2018) 33 Yuridika. 